\title{
NERVE CONDUCTION VELOCITY IN THE DOG DURING HYPOTHERMIA: EFFECTS OF CONTROLLED HYPERCAPNIA*
}

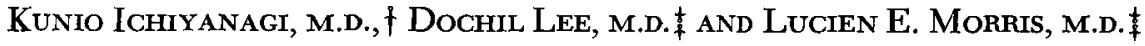

REPORTS on peripheral nervous system function during induced total body hypothermia have been scarce. ${ }^{1}$ The majority of previous investigations concerning the effects of cold have been done in mammals by means of local cooling, or in isolated nerve preparations of lower animals in which species difference is likely to be marked. Since total body hypothermia induces distinct functional changes in various organs simultaneously, its effects on the peripheral nervous system may be considerably different from those observed in in vitro preparations or even in nerves cooled locally in situ.

Many of the adverse effects of hypothermia may be attributable to the accompanying acid-base derangement. This probability was the basis for the suggestion by Carson and Morris ${ }^{2}$ of an optimal $\mathrm{pH}$ and $\mathrm{PaCO}_{2}$ which varies relative to temperature change. They developed this concept for the clinical management of patients cooled during extracorporeal circulation, and have reported some evidence of improved physiologic function at lower temperatures, ${ }^{3}$ as well as excellent and rapid recovery. ${ }^{4}$ The method used consists of the addition of carbon dioxide into the pump blood to lower its $\mathrm{pH}$ deliberately by 0.0147 unit for every degree centigrade fall in the temperature.

The present investigation was undertaken to study the effects of hypothermia on some elementary functional modalities of the peripheral nervous system, namely the conduction velocity of nerve impulses and their conduction time across the neuromuscular junction, and to test the validity of the concept of optimal $\mathrm{pH}$ and $\mathrm{PaCO}_{2}$ cited above as it applies to the peripheral nervous system during hypothermia.

\section{Methods}

Five mongrel dogs weighing 8.5 to $24.0 \mathrm{~kg}$ underwent two experiments, each serving as its own control. In the first experiment the animal was anaesthetized with 5 to 7 per cent halothane in oxygen given through a muzzle mask and with a nonrebreathing valve. After the trachea had been intubated the animal was connected to a pump-respirator and was given 2 per cent halothane in oxygen by means of a Fluotec vapourizer. The expiratory halothane concentration moni-

Anesthesia Research Laboratory, Providence Hospital, Seattle, Washington.

"Supported in part by a grant from Ayerst Laboratories, Inc.

$\nmid$ Professor of Anesthesiology, Niigata University School of Medicine, Niigata, Japan.

$\$$ Present address: Department of Anaesthesia, Medical College of Ohio at Toledo. 
tored on a halothane-vapour analyzer* became stable at $1.5 \pm 0.1$ per cent, 30 to 40 minutes after intubation. By monitoring end-tidal $\mathrm{CO}_{2}$ concentration continuously on an infrared $\mathrm{CO}_{2}$ analyzert and measuring $\mathrm{PaCO}_{2}$ at intervals the respiratory volume could be adjusted in such a way that $\mathrm{PaCO}$.2 was maintained a few torr below the respiratory threshold ( 35 to 45 torr) so that there was neither spontaneous respiratory activity nor gross hyperventilation of the lungs.

A cannula inserted into a femoral artery was used for blood sampling and for continuous blood pressure measurement. Oesophageal temperature was measured at heart level continuously with a thermistor probe and a telethermometer + . By means of a needle-type thermistor probe the same meter was used to record the temperature of a muscle mass in the foreleg in which the ulnar nerve conduction velocity was to be measured.

After stable anaesthetic and respiratory conditions had been established for at least 30 minutes the animal was cooled slowly with ice-bags and refrigerant blankets to approximately $25^{\circ} \mathrm{C}$ (oesophageal) and subsequently rewarmed to the precooling temperature. In order to minimize differences in perineural temperature localized cooling of the extremity was avoided. The inspired halothane concentration was maintained constant throughout the procedure. Conduction velocity was recorded at appropriate temperature levels and arterial blood samples were drawn simultaneously for gas analyses. The time required for the cooling and rewarming averaged $4^{1 / 2}$ hours for the control and $4^{1 / 4}$ hours for the $\mathrm{pH}$ adjustment experiments.

Arterial blood samples were analyzed for $\mathrm{PaCO}_{2}$ and $\mathrm{pH}$ by means of an electrode system kept at $37^{\circ} \mathrm{C}$ and read on a Beckman Physiological Gas Analyzer. $\$$ Values were corrected to body temperature using appropriate temperature correction factors. ${ }^{5,6}$ In three animals serum $\mathrm{Na}^{+}$and $\mathrm{K}^{+}$concentrations were also measured.

In the second experiment, five to seven days later, the animal was anaesthetized and its temperature changed in the same manner as in the first experiment except that the arterial blood $\mathrm{pH}$ was altered by adding $\mathrm{CO}_{2}$ to the respired anaesthetic atmosphere in an amount sufficient to reduce the $\mathrm{pH}$ by 0.0147 unit for every ${ }^{\circ} \mathrm{C}$ fall in oesophageal temperature.

In the preliminary experiments effects of altered levels of anaesthesia on the conduction velocity were observed in three animals under normothermia by varying the inspiratory halothane concentrations from 0.75 per cent to 7.0 per cent by approximately 2 per cent increments. In ten other animals effects of altered $\mathrm{PaCO}_{2}$ ( 10 to 145 torr), achieved by varying ventilatory volume and inspiratory $\mathrm{CO}_{2}$ concentration, were determined under normothermia and a stable anaesthetic level ( 1.5 per cent expiratory halothane). In two animals the ulnar nerve was continuously stimulated electrically for three and four hours, respectively, under normothermia and a stable anaesthetic level in order to observe if nerve conduc-

* Fluothane Monitor: Analytic System Co., Pasadena, California.

tCapnograph Type KK: Godart, de Bilt, Holland.

tTelethermometer, Model 43 TD: Yellow Springs Instrument Co., Yellow Springs, Ohio.

§eckman Physiological Gas Analyzer; Model 160: Beckman Instruments, Inc., Palo Alto, California. 


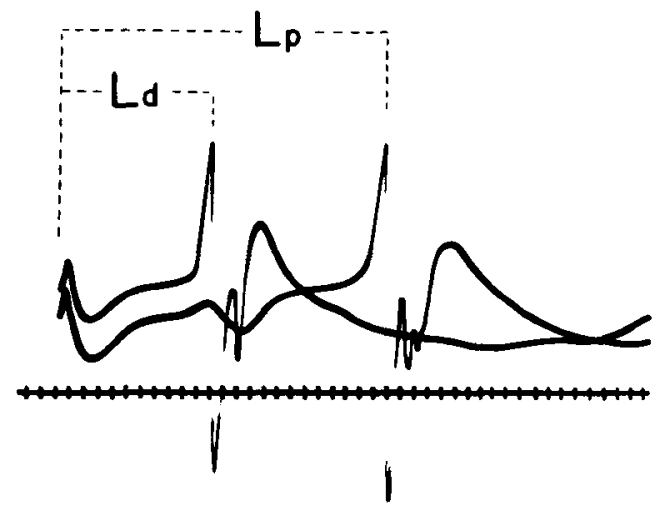

\section{SA $\quad R_{d} \quad R_{p}$}

Figure 1. A typical record of electromyogram. SA: Stimulus artifact; Rd: Response to distal stimulus; Rp: Response to proximal stimulus; Ld: Latency to distal stimulus; Lp: Latency to proximal stimulus.

Conduction velocity $(\mathrm{m} / \mathrm{sec})=\frac{\text { Interelectrode distance }(\underline{\mathrm{mm}})}{\mathrm{Lp}-\mathrm{Ld}(\mathrm{msec})}$

Terminal conduction time $(\mathrm{msec})=\mathrm{Ld}$

tion velocity would change during this period of time because of the continuous stimulation.

Nerve Conduction Velocity: Conduction velocity was determined in a standard manner. The ulnar nerve was stimulated alternately through two pairs of percutaneous needle electrodes, the proximal pair being placed at the point where the nerve crosses the medial epicondyle of the humerus and the distal pair at the point where the terminal palmar branch passes medial to the accessory carpal bone. The cathodes of both pairs were placed distally. Stimuli used were supramaximal square wave pulses ( 1.5 times the maximal stimulus at precooling perineural temperature of 33 to $35^{\circ} \mathrm{C}$ ). They were of $0.2 \mathrm{msec}$ duration and of one per 2-sec frequency. Concentric needle-type recording electrodes were inserted into an appropriate muscle mass of the palm. Electromyographic responses to the proximal and distal stimuli, displayed on an oscilloscope, were photographed. A typical record is shown in Figure 1.

Nerve conduction velocity $(\mathrm{m} / \mathrm{sec})$ was obtained by dividing the distance $(\mathrm{mm})$ between the two pairs of stimulating electrodes by the conduction time (msec) across these electrodes. The latter is the difference between the latencies of the action potentials to proximal and distal stimuli. As it was not always possible to identify the sharp rising point of the compound action potential the latencies to the maximal responses were used in the determination of the conduction time. The conduction velocity obtained in this manner is thus the mean conduction velocity of the ulnar motor nerve fibers.

Terminal Conduction Time: The terminal conduction time, i.e., the latency to the distal stimulus ( $\mathrm{Ld}$ in Figure 1) represents the conduction time between the 


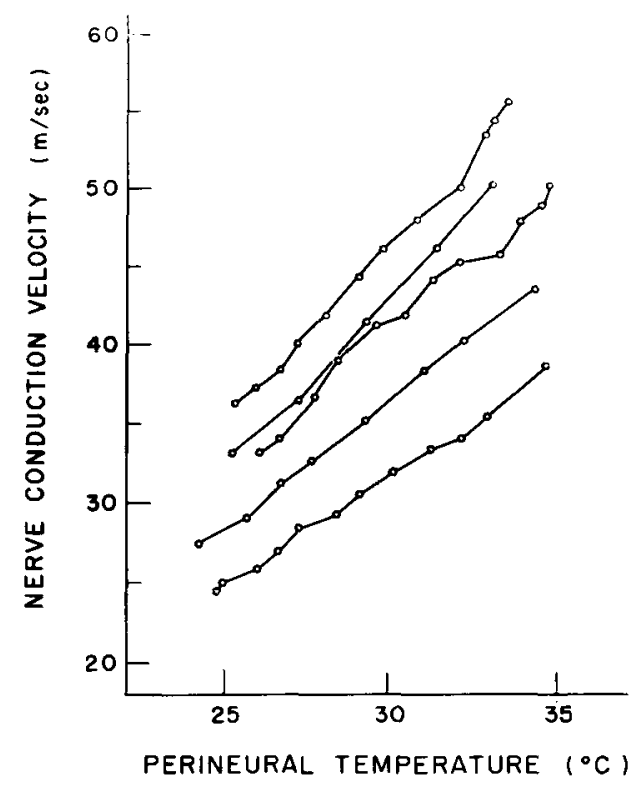

Figure 2. Effect of perineural temperature on nerve conduction velocity during cooling without $\mathrm{pH}$ adjustment. Changes during rewarming are omitted for the sake of clarity.

distal stimulating electrodes and the recording electrodes. This moiety is a qualitative reflection of the time required for the nerve impulses to cross the neuromuscular junction.

\section{Results}

In the preliminary experiments under normothermia with strict maintenance of perineural temperature no significant change in the conduction velocity was produced by continuous electrical stimulation for periods up to four hours nor by considerable variation in the level of anaesthesia or $\mathrm{PaCO}_{2}$ (see Merhods).

In each of five animals of the control experiment conduction velocity decreased in a linear fashion as perineural temperature was reduced within the range between 35 and $23^{\circ} \mathrm{C}$ (Figure 2). The linear relationship was highly significant in each animal $(\mathrm{P}<0.001)$. The large scatter of the lines is due to inevitable inaccuracy of measurement of the distance between the two pairs of stimulating electrodes, though this inaccuracy does not affect the slope of the individual lines. The mean regression equation expressing this relationship is presented in Table I. In the control experiment the nerve conduction velocity decreased by an average of $1.82 \mathrm{~m} / \mathrm{sec}$ for every degree centigrade fall in the perineural temperature. The relationship was also linear during rewarming but the mean slope of the regression lines for rewarming $\left(1.65 \mathrm{~m} / \mathrm{sec} /{ }^{\circ} \mathrm{C}\right)$ was less than that for cooling $(\mathrm{P}<0.025)$.

In the $\mathrm{pH}$-adjustment experiments conduction velocity also bore a linear relationship to the perineural temperature (Table I). The slope of the regression 
ICHIYANAGI, $e t$ al. : NERVE CONDUCTION VELOCITY IN THE DOG

TABLE I

Relationship Between Conduction Velocity and Perineural Temperature

\begin{tabular}{ccc}
\hline Experiment & Cooling & Rewarming \\
\hline $\begin{array}{c}\text { Control } \\
(\mathrm{n}=5)\end{array}$ & $\mathrm{V}=1.82 \mathrm{t}-15.05$ & $\mathrm{~V}=1.65 \mathrm{t}-9.85$ \\
$\begin{array}{c}(\mathrm{SE}=0.184) \\
(\mathrm{n}=5)\end{array}$ & $\mathrm{V}=1.82 \mathrm{t}-15.73$ & $\mathrm{~V}=1.56 \mathrm{t}-9.42$ \\
$(\mathrm{SE}=0.215)$ & $(\mathrm{SE}=0.250)$ \\
\hline
\end{tabular}

$\mathrm{V}$ : Conduction velocity in $\mathrm{m} / \mathrm{sec}$.

$\mathrm{t}$ : Perineural temperature in ${ }^{\circ} \mathrm{C}$.

$\mathrm{SE}$ : Standard error of the mean of coefficients for $t$.
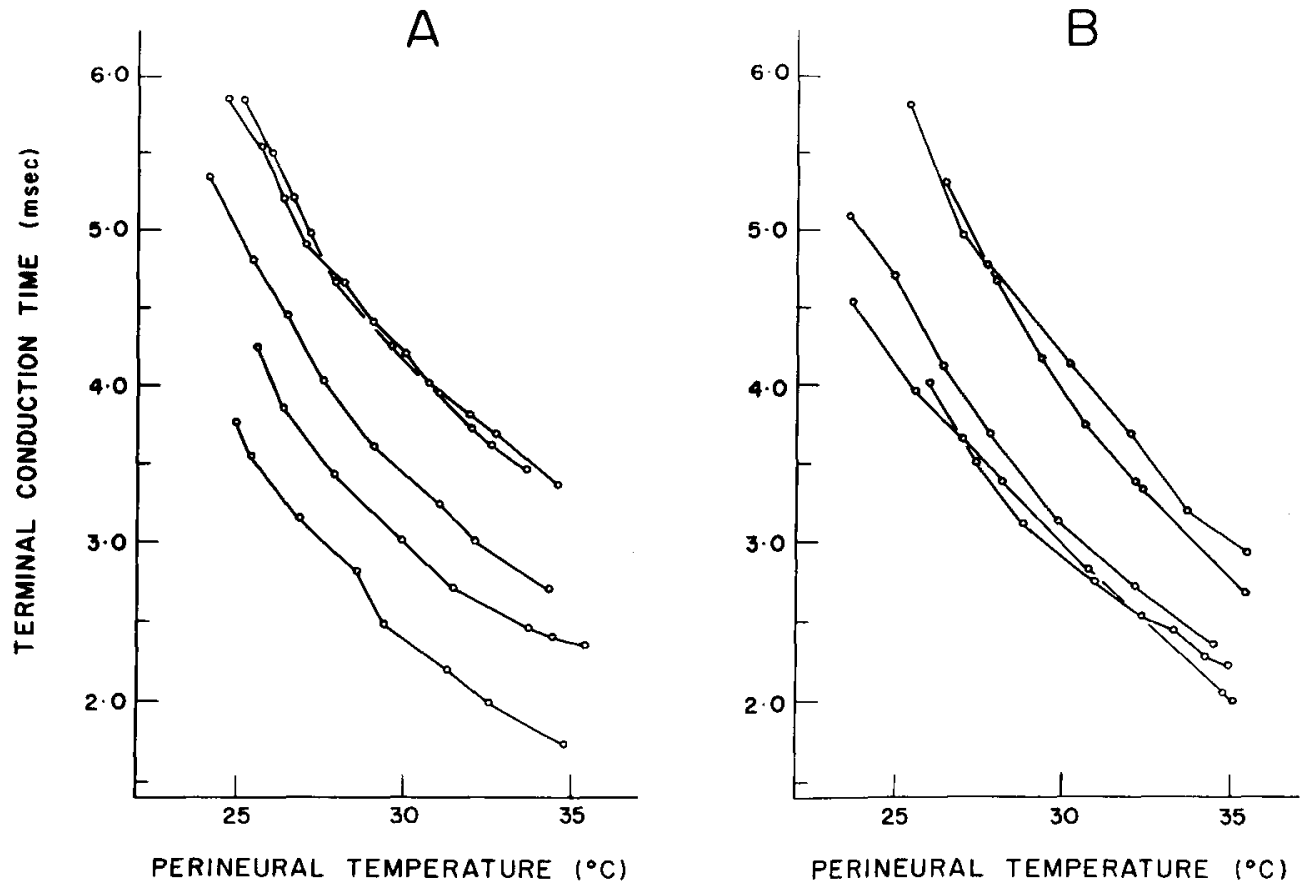

Frgure 3. Effect of hypothermia on terminal conduction time. A: Control experiment. B: $\mathrm{pH}$-adjustment experiment.

line for rewarming $\left(1.56 \mathrm{~m} / \mathrm{sec} /{ }^{\circ} \mathrm{C}\right)$ was again less than that for cooling $(1.82$ $\left.\mathrm{m} / \mathrm{sec} /{ }^{\circ} \mathrm{C}\right)(\mathrm{P}<0.025)$. There was no significant difference in the slopes of the regression lines for either cooling, or rewarming between the control and the $\mathrm{pH}$ adjusted experiments.

In contrast to the conduction velocity the terminal conduction time was prolonged in a non-linear fashion in relation to the reduction in the perineural temperature both in the control and the $\mathrm{pH}$-adjusted experiments (Figure 3). No attempt has been made to define the nature of these curves nor to compare the results of two experiments quantitatively, since the terminal conduction time involves certain indeterminate factors such as the length of the nerve and muscle fibers, and the mode of muscle fiber conduction. The lesser linearity of some 
TABLE II

Changes in Metabolic Component of Acid-Base Status During Hypothermia (BASE EXCESS IN MEQ/L)

\begin{tabular}{|c|c|c|c|c|}
\hline \multirow[b]{2}{*}{ Animal } & \multicolumn{2}{|c|}{ Control } & \multicolumn{2}{|c|}{ pH-adjustment } \\
\hline & Range & Maximal change* & Range & Maximal change* \\
\hline $\begin{array}{l}1 \\
2 \\
3 \\
4 \\
5 \\
5\end{array}$ & $\begin{array}{r}3.2--2.1 \\
0.0--3.5 \\
3.5-0.0 \\
-4.0--6.0 \\
7.5--1.8 \\
\end{array}$ & $\begin{array}{r}-5.3 \\
-3.5 \\
0.0 \\
-0.1 \\
-5.7\end{array}$ & $\begin{array}{r}-1.9--12.7 \\
1.0=-4.0 \\
-7.5=-12.6 \\
-4.0=-8.3 \\
2.0--6.0\end{array}$ & $\begin{array}{l}-9.5 \\
-1.5 \\
-2.4 \\
-4.3 \\
-8.0 \\
\end{array}$ \\
\hline
\end{tabular}

*Maximal change towards acidosis in relation to the precooling value.

curves as compared to others may have been due to longer nerve fiber components being included in the terminal portion of the neuromuscular unit tested.

$\mathrm{PaCO}_{2}$, corrected to the body temperature, ranged between 15 and 41 torr at the lowest oesophageal temperature in the control experiments whereas it was between 51 and 85 torr in the $\mathrm{pH}$-adjusted experiments. Changes in the acidbase status are presented in Table II. Slightly larger base deficit values for the pH-adjusted experiments are probably more apparent than real being due to the discrepancy between in vivo and in vitro behaviour of arterial blood in the presence of acute hypercapnia. ${ }^{7}$ There was a tendency for serum $\mathrm{K}^{+}$to decrease during cooling and to increase during rewarming; the range for the control experiments was between 2.9 and $4.8 \mathrm{mEq} / 1$, and that for the $\mathrm{pH}$-adjustment experiments, between 3.1 and $7.0 \mathrm{mEq} / 1$. There was no distinct trend of changes in serum $\mathrm{Na}^{+}$; the range for the control experiments was between 139 and 147 $\mathrm{mEq} / 1$ and that for the $\mathrm{pH}$-adjusted experiments was between 139 and 149 $\mathrm{mEq} / 1$.

\section{Discussion}

The linear relationship between the nerve conduction velocity and the perineural temperature found in the present study agrees with findings in unanaesthetized man. Johnson and Olsen ${ }^{8}$ observed an average decrease of nerve conduction velocity of $2.8 \mathrm{~m} / \mathrm{sec} /{ }^{\circ} \mathrm{C}$ in the ulnar and median nerves induced by local cooling. Warming of the extremities brought about changes of a similar magnitude in the opposite direction. Henriksen" also reported an average decrease of 2.4 $\mathrm{m} / \mathrm{sec} /{ }^{\circ} \mathrm{C}$ in the cooled ulnar nerve. The different rates of decrease presented by these and by the present authors can be attributed to several factors, such as species difference, ${ }^{10}$ age, ${ }^{11}$ nature and size of the nerve tested ${ }^{1,12}$ and errors inherent in the technique. ${ }^{13}$ That the presence of inhalational anaesthesia in our study might have contributed to this difference seems unlikely because in our preliminary experiments the conduction velocity was little affected by considerable variation of the anaesthetic level. This agrees with the findings of other investigators. ${ }^{1,14,15}$

De Jong and his associates ${ }^{1}$ also reported a linear relationship between perineural temperature $\left(35^{\circ} \mathrm{C}\right.$ to $\left.23^{\circ} \mathrm{C}\right)$ and conduction velocity in the peroneal nerve of anaesthetized hypothermic man. Since no blood gas data were given in 
their study their findings are not directly comparable to ours, but it is of interest to note that the average rate of decrease in their subjects was $1.84 \mathrm{~m} / \mathrm{sec} /{ }^{\circ} \mathrm{C}$ as compared to $1.82 \mathrm{~m} / \mathrm{sec} /{ }^{\circ} \mathrm{C}$ in the present investigation. Considering the numerous variables cited above the almost identical values obtained are probably coincidental.

Regression equations relating the conduction velocity to the perineural temperature in our study suggest that nerve conduction would cease at approximately $8.5^{\circ} \mathrm{C}$ if the excitability of the nerve fibers remained the same down to this temperature, although some evidence against the latter assumption has been put forward. ${ }^{1}$ The figure is close to the one reported for the myelinated nerve fibers of the cat $\left(7.6 \text { to } 9.1^{\circ} \mathrm{C}\right)^{12}$ and to that proposed for the peroneal nerve of hypothermic man $\left(9.1^{\circ} \mathrm{C}\right) .^{1}$

The present study has been carried out in part to test the applicability of the concept of optimal $\mathrm{pH}$ and $\mathrm{PaCO}$. to the peripheral nervous system. Deliberate lowering of arterial blood $\mathrm{pH}$ by means of increasing $\mathrm{PaCO}_{2}$ according to a precalculated scale did not affect the rate of decrease in the conduction velocity during cooling nor did it prevent the delay in its recovery during rewarming. This inability of altered $\mathrm{pH}$ and $\mathrm{PaCO}_{2}$ to affect the nerve response to temperature change is probably due to the incomparably larger physical effect of cold itself as compared to the effects of other environmental factors, such as $\mathrm{PaO}_{2}$, $\mathrm{PaCO}_{2}, \mathrm{pH}$, electrolyte and anaesthetic levels.

It has been pointed out by many investigators that the major source of experimental error in this type of work is the difficulty of controlling the perineural temperature. On the other hand the preliminary experiments demonstrated that variation in anaesthetic level, $\mathrm{PaCO}_{22}$ and extracellular acid-base status did not affect the conduction velocity noticeably, as long as the perineural temperature remained rigidly controlled. These findings are in agreement with the results of previous studies by other investigators in which the magnitudes of environmental changes were similar to those in the present study. Lorente de Nón ${ }^{16}$ observed no change in the conduction velocity of cat and frog nerves exposed to 5 per cent $\mathrm{CO}_{2}$ in vitro. Simpson, ${ }^{17}$ having found that in man conduction velocity was not affected by hypokalaemia, hyperkalaemia, hyponatraemia, hypocalcaemia or chronic hypoxia, concluded that the range of metabolic changes encountered in human diseases is insufficient to cause alteration of conduction velocity. It follows that temperature itself seems undoubtedly the most important determinant of conduction velocity because of the close dependence of the electrical properties of the nerve fiber membrane on temperature change.

Although at a glance there seems no significant difference between the results of the control and the $\mathrm{pH}$-adjusted experiments (Figure 3) interpretation of the change in the terminal conduction time and its mathematical expression is difficult, since the terminal portion of the neuromuscular unit tested includes unknown lengths of nerve and muscle fibers. Furthermore the mode of conduction in the latter is also unknown. It may suffice here to say that the concept of optimal $\mathrm{pH}$ and $\mathrm{PaCO}_{2}$ may be more applicable to the complex trans-synaptic conduction than to simple axonal conduction, but to test the validity of this proposal a more refined experimental technique is required. 


\section{SUMMARY}

Effects of hypothermia on the nerve conduction velocity and conduction time across the neuromuscular junction (terminal conduction time) were studied in the range between 35 and $23^{\circ} \mathrm{C}$ using the in situ ulnar nerve of the dog. Nerve conduction velocity decreased in linear fashion with the reduction in the perineural temperature at an average rate of $1.82 \mathrm{~m} / \mathrm{sec} /{ }^{\circ} \mathrm{C}$. Recovery occurred in a similar linear relationship on rewarming but at the slightly lesser rate of 1.65 $\mathrm{m} / \mathrm{sec} /{ }^{\circ} \mathrm{C}$. This rate of change in the conduction velocity was not altered by deliberate lowering of arterial blood $\mathrm{pH}$ according to a precalculated scale, i.e. $0.0147 \mathrm{pH}$ unit decrease per degree centigrade fall of oesophageal temperature. These changes of $\mathrm{pH}$ were achieved by raising the $\mathrm{PaCO}_{2}$. The lack of effect of altered $\mathrm{pH}$ and $\mathrm{PaCO}_{2}$ is ascribed to the much greater effect of cold itself as compared to other environmental factors.

The prolongation of terminal conduction time was non-linear to the reduction in the perineural temperature and recovered also in nonlinear fashion during rewarming. This lack of linearity is probably due to the more complex manner of depression by cold of neuromuscular transmission as compared to axonal conduction.

\section{RÉSUMÉ}

Nous avons étudié, in situ, sur le nerf radial du chien les effets de l'hypothermie, variant de $35^{\circ}$ à $23^{\circ} \mathrm{C}$, sur la vitesse de conduction du nerf périphérique et sur la vitesse de conduction à la jonction neuromusculaire (vitesse de conduction terminale). La vitesse de conduction nerveuse a ralenti de façon linéaire avec l'abaissement de la $\mathrm{T}^{\circ}$ périneurale à un rythme moyen de $1.82 \mathrm{~m} / \mathrm{sec} /{ }^{\circ} \mathrm{C}$. Cette allure du changement de la vitesse de conduction n'était pas influencée par l'abaissement volontaire du $\mathrm{pH}$ du sang artériel selon une échelle précalculée soit 0.0147 unité d'abaissement par degré $\mathrm{C}^{\circ}$ de chute de température oesophagienne. Cette modification a été obtenue en augmentant la $\mathrm{PaCO}_{2 .}$. L'inefficacité des modifications du $\mathrm{pH}$ et de la $\mathrm{PaCo}_{2}$ est assujettie à l'effet beaucoup plus grand du froid, lui-même comparé aux autres facteurs environnants. La vitesse de conduction terminale a ralenti de façon non-linéaire avec l'abaissement de la $\mathrm{T}^{\circ}$ périneurale. Cette nonlinéarité est probablement attribuable à une manière de dépression par le froid beaucoup plus complexe de la transmission neuromusculaire comparée à la conduction anoxale.

\section{REFERENCES}

1. De Jong, R.H., Hershey, W.N., \& Wagman, I.H. Nerve conduction velocity during hypothermia in man Anesthesiology 27: 805-810 (1966).

2. Carson, S.A.A. \& MORRIs, L.E. Controlled acid-base status with cardiopulmonary bypass and hypothermia. Anesthesiology 23: 618-626 (1962).

3. Morris, L.E., Carson, S.A.A., \& Tomin, P.J. Respiratory threshold in hypothermia. Anesthesiology 28: 263 (1967).

4. Carson, S.A.A., Morris, L.E., Edmark, K.W., Jones, T.W., Logan, G.A., Sauvage, L.R., \& Thomas, G.I. Acid-base management for open-heart surgery. Circulation 29: 456466 (1964).

5. Bradley, A.F., Stupfel, M., \& Severinghaus, J.W. Effect of temperature on $\mathrm{PCO}_{2}$ and $\mathrm{Po}_{2}$ of blood in vitro. J. Appl. Physiol. 9: 201-204 (1956). 
6. Rosenthal, T.B. The effect of temperature on the $\mathrm{pH}$ of blood and plasma in vitro. J. Biol. Chem. 137: 25-30 (1948).

7. Cohen, J.J., Bracketr, N., Jr., \& Schwartz, W.B. The nature of the carbon dioxide titration curve in the normal dog. J. Clin. Invest. 43: 777-786 (1964).

8. Johnson, E.W., \& OLSEN, K.J. Clinical value of motor nerve conduction velocity determination. J. Amer. Med. Assoc. 172: 2030-2035 (1960).

9. Henriksen, J.D. Conduction velocity of motor nerves in normal subjects and patients with neuromuscular disorders. Thesis, Univ. of Minnesota (October 1956).

10. Chatfiexd, P.O., Lyman, C.P., \& Irveng, L. Physiological adaptation to cold of peripheral nerve in the leg of the herring gull (larus argentatus). Amer. J. Physiol. 172: 639644 (1953).

11. Nonrs, A.H., Sноck, N.W., Wagman, I.H. Age changes in the maximum conduction velocity of motor fibers of human ulnar nerves. J. Appl. Physiol. 5: 589-593 (1953).

12. Paintal, A.S. Block of conduction in mammalian myelynated nerve fibres by low temperatures. J. Physiol. 180: 1-19 (1965).

13. Chrustie, B.G. \& Coomes, E.N. Normal variation of nerve conduction in three peripheral nerves. Ann. Phys. Med. 5: 303-310 (1960).

14. Thonnton, J.A., Whelpton, D., \& Brown, B.H. The effect of general anaesthetic agents on nerve conduction velocities. Brit. J. Anaesth. 40: 583-587 (1968).

15. DE JONG, R.H. \& NACE, R.A. Nerve impulse conduction and cutaneous receptor responses during general anesthesia. Anesthesiology 28: 851-855 (1967).

16. Lonente DE Nó R. Carbon dioxide and nerve conduction. Rockefeller Inst. Med. Res. 131: 148 (1947).

17. Simpson, J.A. Conduction velocity of nerves in human metabolic disorders. Electroenceph. Clin. Neurophysiol. 10: 355 (1958). 